\title{
Visual Framing with Humorous Approach for Gojek's J3K Initiative Video
}

\author{
Elda Franzia Jasjfi ${ }^{1}$, Stephani Calista Nainggolan ${ }^{2}$, RA Heryani Wahyuningrum ${ }^{3}$ \\ \{elda@trisakti.ac.id ${ }^{1}$ \}
}

Visual Communication Design Program, Faculty of Art and Design, Universitas Trisakti, Jl. Kyai Tapa no. 1, Jakarta, Indonesia ${ }^{1,2,3}$

\begin{abstract}
Gojek is a technology company that reaches Indonesian people through online services. Gojek continues to innovate and be creative in various promotional media, and is increasingly recognized for its advertisements on social media. There are 2 (two) Gojek public service advertisement videos with the theme of J3K which are broadcasted through Gojek Indonesia's YouTube media, namely "J3K: Agar Nyaman dalam perjalanan pake Gojek" from the driver's point of view and "Cara aman hidup nyaman pake Gojek" from the customer's point of view. These two videos are about one minute long to convey the J3K principle (Jaga Kesehatan, Jaga Kebersihan, Jaga Keamanan or maintaining safety, health and hygiene) that drivers and customers need to remember and implement in order to work and be active during this COVID-19 pandemic. Both videos are animated videos with moving frame visualizations. This research examines how characters, visuals and framing are used to conveying the message of the J3K Gojek campaign with a humorous approach. The method used is descriptive qualitative with literature analysis of the visual screen capture of the advertisement video. The result of the analysis is an understanding of visual framing with a humorous approach taken by Gojek in communicating the $\mathrm{J} 3 \mathrm{~K}$ initiative to the Indonesian people.
\end{abstract}

Keywords: gojek; humor; video; visual; framing

\section{Introduction}

Gojek is a technology company that serves the Indonesian people through online transportation services. Transportation service sector began in 2010 as a call center for ojek services with 20 motorbikes. Carrying three pillars, namely Speed, Innovation, and Social Impact, Gojek developed into an application to meet other needs, such as delivery of goods, ordering food, paying bills, and so on. Apart from Indonesia, Gojek also reaches neighboring countries, namely Singapore, Thailand, and Vietnam [1]. Gojek is known for its various services, communications, and the role of visual communication design in its promotional media, especially social media [2].

The J3K initiative was launched in October 2020 [3], at a time when the COVID-19 pandemic was increasing in Indonesia and affecting people's lives and activities. $\mathrm{J} 3 \mathrm{~K}$ is 
Gojek's principle in implementing new life guidelines for daily activities during the COVID19 pandemic. J3K stands for Jaga Kesehatan, Jaga Kebersihan, and Jaga Keamanan or maintaining safety, health and hygiene [4]. This J3K principle is Gojek's commitment to help the community adapt during the pandemic. This principle is not only intended for Gojek's driver-partners so that they can continue to work during the pandemic, but also to invite the customer community to do the same thing that is conveyed through public service advertisement videos with a humorous approach.

The humorous approach is often used in advertising. Research from Kovindasamy and Ogundare [5] and Primanto and Dharmmesta [6] suggests that humor attracts consumers to pay attention to advertisements and influences consumers decision in purchasing products. Humor is closely related to the social culture of the consumers, because the message of humor conveyed in an advertisement is successful if it is specific to the socio-culture of the target consumer. Gojek also often uses humor in its advertisements. Research from Widya, Erisanti, Triwulandari [7]; Farhan and Maryani [8]; Priana and Suwandi [9], suggested that Gojek's creative strategy with a humorous approach to advertisements on YouTube became Gojek's attraction, thereby increasing Gojek's brand awareness.

There are 2 (two) public service advertisement videos about the J3K initiative on YouTube namely Video 1 "J3K: Agar Nyaman dalam perjalanan pake Gojek" which was published on July 6, 2020 with a duration of 1.18 minutes [10] and Video 2 "Cara aman hidup nyaman pake Gojek" which was published on August 10, 2020 with a duration of 1.00 minutes [11]. The two videos show a series of J3K activities carried out by Gojek drivers and customers in the form of animated videos using visual framing equipped with text and audio narrator. This public service advertisement is interesting to be studied in more depth because it displays a simple visual animation but is able to attract attention and convey a message with a humorous approach. Previous research from Barlaman [12] has analyzed the impact of Gojek's J3K advertisement on YouTube for brand image during the pandemic. However, this research will focus on the study of the visual framing used in the two Gojek public service advertisement videos to communicate the message of this J3K campaign to the Indonesian people.

\section{Method}

The research method used is descriptive qualitative method. Qualitative research is research that emphasizes understanding of problems in social life based on holistic, complex, and detailed reality conditions [13]. Qualitative research focuses on theory and the relationship between theory and data obtained in the field, so that the purpose of qualitative research is to find meaning from critical thinking comprehensively. Sources of data used in this research came from primary and secondary data sources. Primary data was obtained directly through Gojek Indonesia's YouTube channel media to directly observe J3K public service advertisement videos. Secondary data to support primary data is obtained from literature studies related to this research. The data collection method is visual observation and video screen capture which is the object of the research. This data source is used in the visual framing analysis of the J3K Gojek's advertisement. The analysis variables are visual characters, visual framing, and $\mathrm{J} 3 \mathrm{~K}$ messages with a humorous approach delivered through Video 1 dan Video 2.

\section{Result and Discussion}


The $\mathrm{J} 3 \mathrm{~K}$ initiative is a campaign echoed by Gojek and introduced through the website and YouTube media to increase public trust in online transportation during the COVID-19 pandemic. The message of Jaga Kesehatan or maintaining health contains a series of actions to help protect and maintain the immune system by taking regular vitamins, checking temperature regularly, having adequate sleep and exercising regularly. Jaga Kebersihan or maintaining hygiene is carried out as an effort to increase the sense of security for people around and drivers with standard vehicle hygiene protection, contactless delivery features, and Gocar ProtectShield. Jaga Keamanan or maintaining safety is done by preventing the spread of disease, such as washing hands regularly for 20 seconds, using hand sanitizer when soap and water are not available, bringing personal helmets, and cleaning equipment/gadget regularly with disinfectant [4].

\subsection{Character}

Through the website [4], Video 1 can be accessed. This video is an introduction to the principle of $\mathrm{J} 3 \mathrm{~K}$. It is in the form of animation by showing the character Jek as a driver who interacts with other characters as passengers and health workers. The characters Jo and Jek had previously been introduced by Gojek to the Indonesian people through the YouTube video "Introducing Jo \& Jek" [14] on January 21, 2019 which aims to provide driving guidance to drivers and passengers. According to Priana dan Suwandi [9], this advertisement has a positive and significant impact for Gojek's brand awareness. This advertisement uses a humorous approach with Jo as the passenger and Jek as the driver to introduce riding or driving procedure with Gojek.

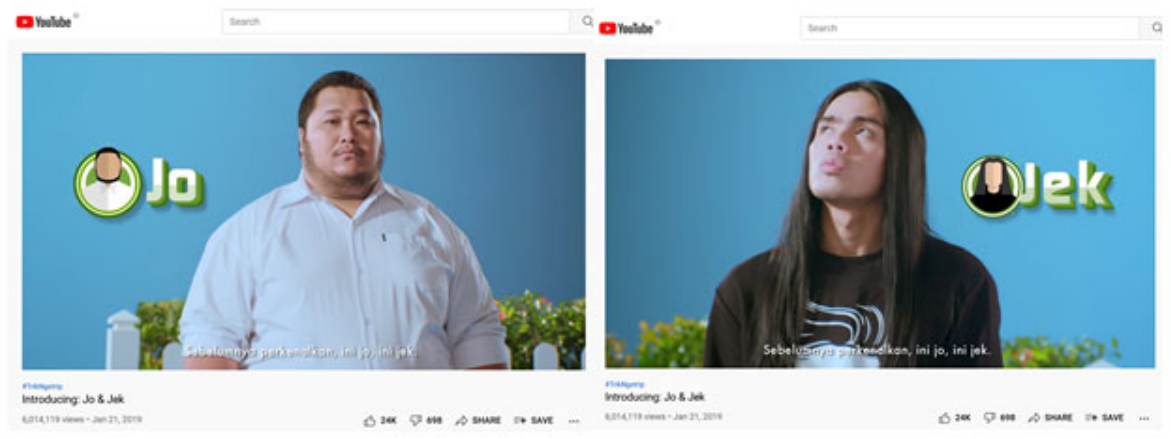

Fig. 1. Screen capture Video "Introducing Jo \& Jek" [14]

Character Jo is introduced as a big man with excess weight, so the Gojek driver's jacket does not fit to be used and therefore Jo is given a position as a passenger. Character Jek becomes the driver and is described as a person who wants to look cool and have a young style. The characterization in this video uses the Superiority theory where laughter occurs because Jo's figure is humiliated due to his appearance, weight, and naivety. Meanwhile, the character Jek becomes the superior figure because he is shown to be cooler as a man with long hair and thinner figure, and that makes him look more ideal, knowledgeable, and understanding. The characters Jo and Jek are shown in Video 1 and Video 2 in the form of animated visuals. 
In Video 1, character Jek appears to communicate the message of the J3K initiative to the driver, while in Video 2, character Jo is reintroduced to inform a message about things that need attention as Gojek's consumer. A humorous approach is used in both videos in order to attract attention and convey the message. Sujoko stated that humor has several functions, including (1) carrying out all the wishes and goals of ideas, (2) making people aware that they are not always right, (3) teaching people to see issues from various perspectives, (4) entertaining, (5) clearing the mind, (6) tolerance, (7) understanding the complicated issue [15]. However, humor is loved by many people because it contains entertainment. The humorous approach has become a part of public communication and an alternative to clear up one's feelings. Through humor, communication can feel familiar and be well received by many people [16]. Since it can be well received and familiar to the public, humor is also used in advertising a brand. According to Shimp (2003), humor is used as an element forming the attractiveness of advertising to achieve goals in communication that are getting attention, influencing attitudes, increasing the reliability of advertising statements, and producing actions in the form of purchases by consumers [17].

\subsection{Visual Framing}

Both videos use animated visuals that set them apart from previous Introducing Jo\&Jek video. The principle of $\mathrm{J} 3 \mathrm{~K}$ is presented and narrated by a female figure who appears in the initial scene, while the next scene uses visual framing which shows the character Jek as a driver who interacts with other characters as passengers and health workers. Framing in a visual context is the lines that limit the image on the top, bottom, left, and right sides, so that the view and focus are centered on the inside of the frame. In communication theory, framing theory relates to the agenda-setting formed by the media so as to form the perception and understanding of media's viewers [18]. According to Rodriguez dan Dimitrova [19] visual framing can identify 4 (four) meanings, namely (1) Visual as a denotative system, (2) Visual as a stylistic semiotic system, (3) Visual as a connotative system, and (4) Visual as a representation ideology. In this Gojek's advertisement, framing is formed by visual communication, which is; (1) denotatively where visuals are framed within lines, (2) as a semiotic communication style of young Indonesian people who are the target of communication, (3) conveying the connotations of various situations faced by drivers and passengers in the COVID-19 pandemic situation, and messages about health are delivered with a humorous approach that is understood by the target audience, that is Indonesian people.

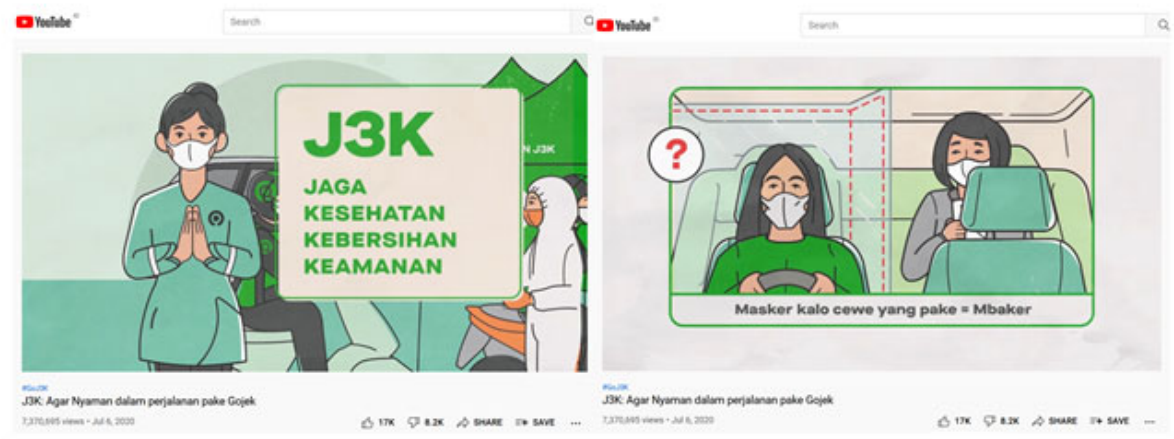

Fig. 2. J3K: Agar Nyaman dalam perjalanan pake Gojek (Jek) [10] 
Video 2 shows an animated video with the same color tone and visual animation style as the previous video which displays visual framing such as the green line that frames the image, accompanied by text at the bottom of the image, and a narrator interacting with character Jo. However, unlike the previous video, the visual framing is not static. Character Jo appears to be able to fall from the top to the bottom frame, or step from the left to the right frame to illustrate the transition of context and situation.

\subsection{Message Communication through Humorous Approach}

Characters Jo and Jek are introduced from the beginning in the Introducing Jo\&Jek video in various situations as passengers - drivers - narrators who introduce themselves as Gojek, with all sorts of conversations containing humorous messages using terms and context that are understood by the younger generation in cities in Indonesia. According to Westbrook \& Chao (2019), humor broadly refers to what is meant to either amuse (or improperly amuse) to overcome the complex and varied nature of humor such as jokes, puns, comedy, satire, sarcasm, parody, stupidity, nonsense, and so on. Humor is used as a communication approach in a variety of contexts from entertainment to politics. There are three major theories regarding humor, which are; (1) Superiority theory, where laughter can occur because someone feels superior to others and the laughter shows humiliation, (2) Relief theory, where laughter occurs to release mental energy consumed by reason to suppressing unreasonable and childish thoughts, and (3) Incongruity theory, where laughter occurs because of feeling confused or surprised by the violation of norms and logical thoughts in an orderly world.

In Video 1, humor is conveyed through puns between Jek - the passenger - the narrator, among others by replacing the word "Masker, kalau perempuan menjadi Mbaker" as shown in Picture 2. While in Video 2, Jo is depicted as big and fat along with the narrator's greeting "Pemirsa yang wajahnya di atas dan di bawah rata- rata". In the next scene, the man turns to the left and makes his face look even. It shows him rejecting the statement that his face is below average and replacing it with "average", meaning not handsome but not ugly. However, the narrator brushes it off by saying "Rata-rata, bukan rata". This humor tends to lead to the Superiority theory where something is considered funny when it feels superior to others and tends to insult. In Video 2, humor is conveyed in the form of words between Jo - the driver the narrator and also through Jo's movement from frame to frame as shown in Picture 3 . This humor is in accordance with the Incongruity theory where something is considered funny when there is inconsistency in logical thinking.

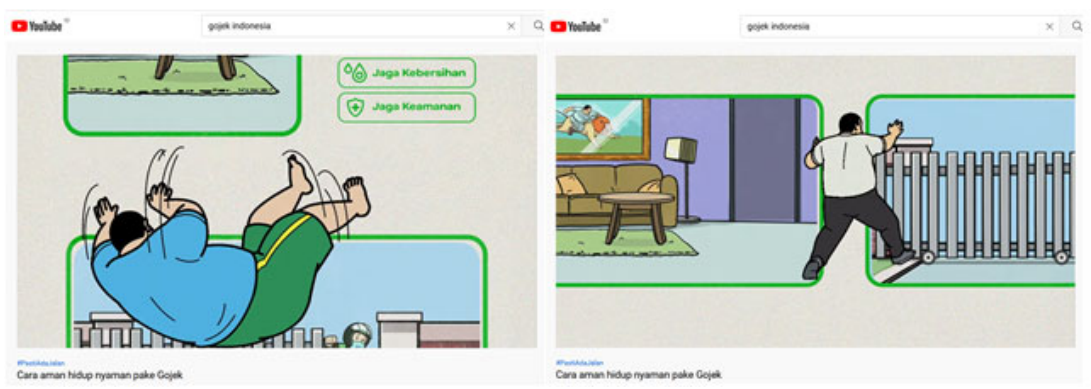

Fig. 3. Cara aman hidup pake Gojek (Jo) [11]

At the end of the advertising video, there are frames which are displayed to describe various situations and messages of action that must be taken by consumers to implement $\mathrm{J} 3 \mathrm{~K}$ 
in interacting using Gojek. The visual frame here functions to limit and focus on visual images and textual messages at the bottom of the frame, that are emphasized by a check mark and which means to be done. Visual framing is used to focus on images in delivering messages to users, namely drivers and passengers, in order to remind them of what needs to be done in maintaining health and safety while using the Gojek application during the COVID-19 pandemic.

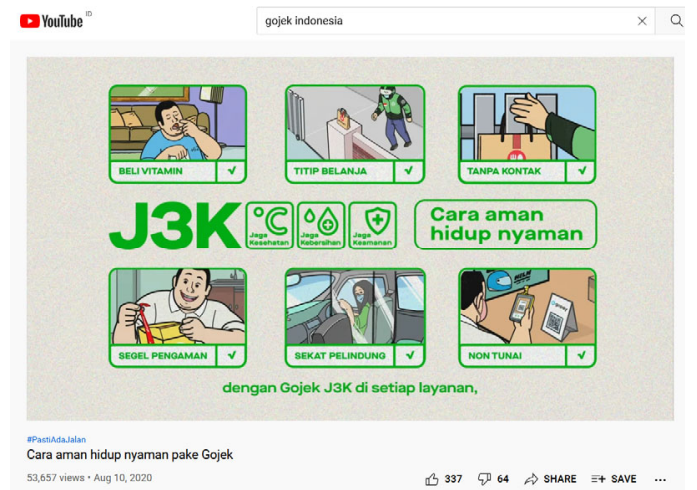

Fig. 4. Framing Cara Aman Hidup Nyaman Pakai Gojek [11]

\section{Conclusion}

Gojek uses a humorous approach to create attention in the $\mathrm{J} 3 \mathrm{~K}$ initiative public service advertisements to the Indonesian people. The element of humor is packaged in the form of visual characters and visual framing, as well as messages in text and audio narrator. The characters Jo and Jek are shown with their respective strengths and weaknesses, in various situations and the context of the message about J3K. Character Jo is presented with Superiority theory where the audience understands the humor due to feelings of superiority from the character. Visual framing is used to limit the view, allow the audience to focus and pay attention, as well as add the visual appeal from the humorous situation. The use of frames also portrays imaginative comics, so that it is in accordance with the humor theory, which is Incongruity theory where something is considered funny when there is inconsistency in logical thinking. Through these two advertisements, Gojek communicates the message about J3K principle that must but carried out to the Indonesian people with a humorous approach with the result that it is interesting and makes the audience follow the story in this advertisement while understanding the J3K campaign message, both as a driver and as a Gojek's user.

\section{Acknowledgment}

The author acknowledges the support provided by the Faculty of Art and Design, Trisakti University, and the Research and Community Development Institution of Faculty of Art and Design, Trisakti University. The author also acknowledges the educational support provided by the Visual Communication Design Program, Faculty of Art and Design, Trisakti University, through the Seminar subject. 


\section{References}

[1] Gojek, "www.gojek.com.” [Online]. Available: https://www.gojek.com/id-id/about/.

[2] G. Y. Pratomo, "Go-Jek Dikenal Berkat Media Sosial," 2015. [Online]. Available: https://www.cnnindonesia.com/teknologi/20150120165729-185-26013/go-jek-dikenalberkat-media-sosial. [Accessed: 22-Sep-2021].

[3] P. G. Indonesia, "Luncurkan Inisiatif Baru lewat J3K, Gojek Bikin Pengguna dan Mitra Makin Terlindungi di Masa Pandemi," Pressrelease.id, 2020. [Online]. Available: https://pressrelease.kontan.co.id/release/luncurkan-inisiatif-baru-lewat-j3k-gojek-bikinpengguna-dan-mitra-makin-terlindungi-di-masa-pandemi?page=all. [Accessed: 22-Sep2021].

[4] Gojek, "J3K." [Online]. Available: https://www.gojek.com/j3k/.

[5] S. K. Kovindasamy and E. A. Ogundare, "A Study of Humour Advertisement and Its Influence on Consumer Purchasing Decision: Evidence From Malaysia," Int. J. Account. Bus. Manag., vol. 5, no. 2, pp. 34-52, 2017.

[6] A. B. Primanto and B. S. Dharmmesta, "What Happens After They Laugh: How Humorous Advertisements Have an Effect on Consumers' Attitudes, Word of Mouth Intentions, and Purchase Intentions, With the Need for Humor Playing a Moderating Role," J. Indones. Econ. Bus., vol. 34, no. 2, pp. 113-127, 2019.

[7] A. D. Widya, L. Erisanti, and E. W. Triwulandari, "Analisis Unsur Humor dalam Penyampaian Pesan pada Iklan Non Komersial Milik Gojek Versi 'Tata Cara Berkendara Bersama Gojek,"' VoxPop, vol. 2, no. 1, pp. 77-87, 2020.

[8] A. M. Farhan and A. Maryani, "Hubungan Daya Tarik Iklan Komedi dengan Brand Awareness (Studi Korelasional Iklan Komedi Go-Jek versi 'Gozali' di Youtube dengan Brand Awareness produk Go-Pay dikalangan Mahasiswa Mankom Unisba Angkatan 2016)," in Prosiding Manajemen Komunikasi, 2016, pp. 351-357.

[9] J. R. Priana and S. Suwandi, "PENGARUH IKLAN 'INTRODUCTION: JO \& JEK' DI YOUTUBE TERHADAP BRAND AWARENESS (Studi Kasus Perusahaan GOJEK)," J. Entrep. Manag. Ind., vol. 2, no. 4, pp. 113-225, 2019.

[10] Gojek, "J3K: Agar Nyaman dalam perjalanan pake Gojek," YouTube, 2020. [Online]. Available: https://www.youtube.com/watch?v=HW-PyoAZRGw.

[11] Gojek, "Cara aman hidup nyaman pake Gojek," YouTube, 2020. [Online]. Available: https://www.youtube.com/watch?v=LVU4VQTXnJ4.

[12] I. F. Barlaman, "Analisis Pengaruh Ikan Gojek di YouTube Versi 'J3K' Terhadap Brand Image Selama Pandemi," Universitas Jember, 2020.

[13] A. Anggito and J. Setiwan, Metode Penelitian Kualitatif. Sukabumi: CV Jejak, 2018.

[14] Gojek, "Introducing: Jo \& Jek," YouTube, 2019. [Online]. Available: https://www.youtube.com/watch?v=oYgCHUKJ-Vc.

[15] D. Rahmanadji, "Sejarah, Teori, Jenis, dan Fungsi Humor," Bhs. Dan Seni, vol. 35, no. 2, pp. 213-221, 2007.

[16] I. Marwan, Semiotika Humor Sufi. Surabaya: UIN Sunan Ampel Press, 2015.

[17] A. M. Ratna and S. Nurfebrianing, "Pengaruh Efektivitas Iklan Dengan Daya Tarik Humor Terhadap Citra Merek," J. Ranah Komun., vol. 2, no. 1, pp. 1-11, 2018.

[18] S. O. Arowolo, "Understanding Framing Theory," 2017.

[19] L. Rodriguez and D. V. Dimitrova, "The Levels of Visual Framing," J. Vis. Lit., vol. 30, no. 1, pp. 48-65, 2011. 
